\title{
Matematik Öğretmen Adaylarında Sigara İçme Alışkanlıklarına İlişkin Kümelenme Eğilimlerinin Matematik Başarısını Yordama Gücü
}

\section{Halil Coşkun ÇELİK*}

Öz: Bu çalışmanın amacı matematik öğretmen adaylarının sigara içme ile ilgili bilgi, tutum ve davranışlarının kümelenme eğilimlerini belirlemektir. Ayrıca bu çalışmada oluşan kümelerin öğretmen adaylarının matematik başarısını yordama gücü araştırılmıştır. Çalışmada öğretmen adaylarının sigara içmeyle ilgili bilgi, tutum ve davranışlarıyla matematik başarısı arasındaki ilişkiyi açıklayan verilerin elde edilmesi noktasında ilişkisel tarama modeli tercih edilmiştir. Araştırma grubunu Güneydoğu Anadolu bölgesinde bulunan bir devlet üniversitesinin, eğitim fakültesi, matematik eğitimi anabilim dalında okuyan ve sigara içen 148 (41 kadın, 107 erkek) matematik öğretmen adayı oluşturmuştur. Araştırmada veriler kişisel bilgi formu, sigara içme anketi ve yıl sonu matematik başarı puan ortalamaları aracılığıyla toplanmıştır. Ward kümeleme yöntemi neticesinde, öğretmen adaylarının sigara içme ile ilgili değişsenlerinin birbirine benzer özelliklerde üç kümede toplandığı belirlenmiştir. Kümeler araştırmanın amacı kapsamında "sigara içmeye ilişkin bilişsel farkındalık", "sigara bağımlılığı ve etkileri" ve “sigaraya yönelik algısal uyarılar ve çevre” şeklinde adlandırılmıştır. Ayrıca elde edilen sigara içme tutum-davranış kümeleri bağımsız değişken ve matematik başarısı bağımlı değişken olmak üzere bir regresyon modeli kurulmuştur. Çoklu regresyon analizi sonucunda da bu kümelerin matematik başarısının yaklaşık \%55'ini açıkladı̆̆ belirlenmiştir.

\footnotetext{
* Dr. Öğr. Üyesi, Siirt Üniversitesi, Eğitim Fakültesi, Email: hcoskun.celik@ gmail.com. https://orcid.org/0000-0003-00565338 
Anahtar Kelimeler: Kümeleme analizi, Matematik eğitimi, Matematik başarısı, Sigara içme alışkanlığı.

\title{
Clustering Tendency of Smoking Habits Mathematics Teacher Candidates' and the Power of Predict Mathematics Success
}

\begin{abstract}
The aim of this study is to determine the clustering tendency of mathematics teacher candidates their knowledge, attitudes and behaviors related to smoking. In addition, the power of predicting the mathematical success of prospective teachers in this study was searched. In
\end{abstract} the study, a relational screening model was chosen at the point where the data describing the relationship between the knowledge, attitudes and behaviors of prospective teachers about cigarette smoking and mathematics success were obtained. The research group formed 148 (41 females, 107 male) smoking prospective teachers of a state university located in the Southeastern Anatolian region, studying at the faculty of education, mathematics education program. The research data were collected through personal information form, smoking questionnaire and year-end math achievement averages. As a result of the Ward connection technique, which has an important role in obtaining optimum clusters from the clustering methods applied to the receive data, the smoking-related variables of teacher candidates are collected in three sets with similar characteristics. Related clusters are called "cognitive awareness on cigarette smoking", "cigarette addiction and effects" and "perceptual stimuli and environment for cigarette smoking" within the scope of the research purpose. A regression model was established in which the smoking attitude-behavioral clusters obtained as a result of the Ward clustering analysis were independent variables and mathematical successdependent variables. As a result of multiple regression analysis, it was determined that these clusters accounted for about $55 \%$ of the mathematical success. 
Keywords: Cluster analysis, Mathematics education, Mathematics success, Smoking habit.

\section{Giriş}

Yaşayan varlıkların en temel yeteneklerinden biri olan ve benzer nesnelerin gruplanmasını içeren sınıflandırma sağlık, biyoloji ve zooloji gibi birçok bilim dalının temelini oluşturur. İnsanlar, hayvanlar, kimyasal elementler ve yıldızlar gibi gruplandırılabilecek oluşumları şekillerine, büyüklüklerine veya tatları gibi belirli özelliklerine göre sınıflandırmak olaylara büyük açıklık ve anlaşılabilirlik kazandırmaktadır (Everitt, Landau ve Leese, 2001). $\mathrm{Bu}$ sayede büyük verilerin çözümlenmesi daha kısa zamanda ve uygun bir şekilde yapılabilmektedir. Veriler geçerli yöntemlerle küçük gruplara uygun şekillerde indirgenebilirse bu grup etiketleri verilerdeki benzerlik ve farklılık modellerinin tanımlanmasına büyük bir açıklık ve anlaşılırlık kazandıracaktır (Everitt, 1974; Tatlıdil, 1996).

Verilerin sınıflandırılmasında genellikle diskriminant analizi, çok boyutlu ölçekleme ve kümeleme analizi gibi çok değişkenli istatistiksel yöntemlere başvurulmaktadır (Çakmak, 1999). Kümeleme analizi bir veri setinin farklı gruplar içerip içermediğini belirlemek ve eğer içeriyorsa bu grupları tespit etmek için kullanılan çok değişkenli istatistiksel yöntemlerin genel adıdır (Wu, Milton, Hammond ve Spear, 1999). Bu yöntem, çok boyutlu uzayda verilerin özetlenmesini ve tanımlanmasını, heterojen olan farklı gruplardaki gözlem yapılarını ya da nispeten homojen olan benzer gruplardaki gözlemleri uygun yöntemlerle gruplamaya olanak sağlar (Mucha ve Sofyan, 2003). Kümeleme analizinin amacı, bir veya birkaç özellik açısından benzer olan nesneleri veya değişkenleri belirlemektir (Gürsoy, 2009). Verilere ilişkin dağılım grafiklerinin görsel kontrolünden, kompleks istatistiksel modellerin uygun hale getirilip sınıflandırılması ve sayısal sınırlardan bir küme seti oluşturmak için birçok yöntem vardır. $\mathrm{Bu}$ 
yöntemler, kümeleme analizinin bir ürünü olan benzer veri yapılarına uygulandığında farklı çözümler ya da kümelemeler ortaya çıkarabilmektedir (Everitt, 1995).

Kümeleme analizinde ilk aşama veri giriş aşamasıdır. Verilerin, kümelemeye uygun biçimde girilmesi ile ilgili olan bu aşamada uzaklıklar matrisi elde edilir. İkinci aşama kümeleme yönteminin seçilmesi ve uygulanmasıdır. Son ve en önemli aşama ise sonuç aşaması olup, bu aşamada sonuçların duyarlılığının ve anlamlılığının tartışması yapılır. Sonuçların uygun olmaması durumunda (değişkenlerin uygun olmaması-küme sayısının doğru belirlenmemiş olması) ikinci aşamaya tekrar dönülür (Tatlıdil, 1996). Kullanıcının amacına ve alanına göre değişmekle birlikte, kümeleme analizinin özel amaçları da şu başlıklarla özetlenebilir: 1) Gerçek tiplerin belirlenmesi, 2) Model uyumu (oluşumları gruplandırmak için uygun yapısal düzenlemeleri araştırma), 3) Veri araştırmalarına dayanarak hipotezin kurulması, 4) Hipotezleri test etmek ya da diğer ortalamaların oluşturduğu sınıflandırmaların bir veri setinde olup olmadığının belirlenmesi, 5) Veri yapısının netleștirilmesi, 6) Veri indirgemesi (veriler yerine kümelerin değerlendirilmesi) ve 7) Aykırı değerlerin bulunması (Everitt, 1974; Tatlidil, 1996).

Kümeleme yöntemleri; uzaklık matrisi ya da benzerlik matrisinden yararlanarak birimleri ya da değişkenleri kendi içinde homojen ve kendi aralarında heterojen uygun gruplara ayırırken, grupları belirlemede (kümelemede) izledikleri yaklaşımlara göre iki temel gruba ayrılırlar. Bunlar aşamalı (hiyerarşik) ve aşamalı olmayan (hiyerarşik olmayan) kümeleme yöntemleridir. Aşamalı kümeleme yöntemleri, birimleri birbirleri ile değişik aşamalarda bir araya getirerek ardışık biçimde kümeler belirlemeyi ve bu kümelere girecek elemanların hangi uzaklık (ya da benzerlik) düzeyinde küme elemanı olduğunu belirlemeye yönelik yöntemlerdir (Özdamar, 2002). Aşamalı kümelemede kümeleme işlemi, temel olarak henüz aynı kümede olmayan iki en benzer değişkeni ve onların kümelerini belirlemektir (Gürsoy, 2009). Aşamalı 
kümelemede küme sayısı önceden bilinmemekte ve araştırmacıya bırakılmaktadır. Ancak aşamalı olmayan kümelemede küme sayısının önceden bilindiği varsayılmaktadır. Aşamalı kümeleme yöntemlerinden biri olan Ward tekniği kümeler içindeki varyansı minimum kılmayı amaçlamaktadır. Yani, Ward yönteminde gruplar içi (kümeler içi) hata kareleri toplamı minimize edilmeye çalışılmaktadır. Analizin her aşamasında, her olası küme çiftinin birleşimi düşünülür ve hata kareler toplamının en küçük artışındaki iki küme (en az bilgi kaybına sahip iki küme) birleştirilir. Ward yönteminin sonuçları bir dendogram üzerinde gösterilebilir ve ilgili dendogramda dikey eksen birleşmelerin meydana getirdiği hata kareleri toplamı değerlerini gösterir (Johnson ve Wichern, 2002).

Bireylerin sigara içme tutum-davranışları açısından, kaç kümede toplanabileceği Ward bağlantı tekniği yardımıyla elde edilen dendogramlar yoluyla belirlenebilir. Bugün dünyada, 800 milyonu gelişmekte olan ülkelerde olmak üzere toplam 1.1 milyar kişi sigara içmektedir, bugünkü sigara içme trendleri devam ederse 2030 yılında, yılda 10 milyon kişi sigara içtikleri için öleceklerdir (Soydal ve Ergüder, 2002). Dünya da her gün 80 ile 100 bin genç sigara içmeye başlamaktadır ve ne yazık ki bunların çoğu sağlık açısından aldıkları risklerin bilincinde değillerdir (Soydal ve Ergüder, 2002). İnsanların sağlık ve yaşamlarına süre ve kalite olarak zarar veren önemli etkenlerden biri olan sigara içme alışkanlığı insanların çalışma hayatını ve verimliliğini olumsuz yönde etkileyebilmektedir (Bilir ve Yıldız, 2008). Sigara içenlerin büyük çoğunluğu sigara içmeye büyük oranda gençlik yıllarında başlamaktadır (Özcebe, 2008). Üniversitede okuyan öğrenciler çoğunlukla sigara içme davranışını etkileme olasılığı yüksek olan (kredi yurtlar kurumu, özel yurt ve öğrenci evi) ortamlarda kalmaktadırlar (Çalışkan, 2015). Bu ortamlarda ailelerinden uzaklaşan öğrenciler kendilerini yetişkin olarak hissetmek ve en yakın arkadaşlarına uyabilmek için sigara içmeye başlama gibi kötü 
alışkanlıklar kazanmaktadırlar. Dolayısıyla bu kötü alışkanlıklar onların eğitim yaşamında, özellikle ders başarı durumlarında olumsuz tutumlar sergilemelerine neden olabilmektedir.

Bireyin matematik öğrenmek için göstereceği çaba ve matematiksel kavramları öğrenmeye yönelik yaklaşımlarında duyuşsal faktörlerin (tutum, inanç, özyeterlik vb.) önemli yerlerinin olduğu belirtilmektedir (McLeod, 1992). Öğrencilerin matematik başarısını etkileyen duyuşsal faktörlerden biri de tutumlardır. Matematikle ilgili yaşantılar arttıkça matematiğe karşı olumlu tutumlar azalmaktadır (Altun, 2010). "Öğrenciler matematiğin zor olduğunu ve onu başaramayacağını düşünerek kaygılanmakta ve matematiğe karşı olumsuz tutum sergilemektedir" (Baykul, 2009, s.47; Ertem-Akbaş, 2018). Yapılan çalışmalar matematik tutumu ile başarı arasında anlamlı bir ilişkinin olduğunu göstermiştir (Akhan ve Bindak, 2017). Öğrencilerin matematik dersine karşı olan olumsuz tutumları, öğretmenlerin davranış ve tutumları ile matematik kaygısı başarısızlık nedenleri olarak sıralanabilir (ErtemAkbaş, 2018; Peker ve Mirasyedioğlu, 2003). Oysa öğrencilerin matematik başarısını yordayan ilgili değişkenlerin yanında, kişisel özellikler, sigara içme alışkanlığı da yer alabilmektedir. Alan yazındaki çalışmalar öğrencilerin ders başarı puanları ile sigara içme sıklığı arasında negatif bir ilişkinin olduğunu göstermiştir (Altıntaş ve diğ., 2008; Emekdar ve diğ., 2017).

Matematik başarısını etkileyen önemli değişkenlerin neler olduğu, ilgili değişkenler arasındaki ilişkilerin ortaya konması ve matematik başarısının ne kadarının bu değişsenler tarafından açıklanabildiğinin tespit edilebilmesi için söz konusu değişkenlerin matematik başarısına olan etkilerinin incelendiği çalışmalara ihtiyaç duyulmaktadır. Dolayısıyla bu çalışmada öğrencilerin sigara içme ile ilgili bilgi, tutum ve davranışlarının matematik başarısıyla olan ilişkisi ve matematik başarısını yordama düzeyi belirlenmeye çalışılmıştır. Bunun yanında Türkiye'de sigara ile ilgili yapılmış olan çalışmalarda sigara alışkanlığının sıklığı ortaya konmakla birlikte, insanların hangi nedenlerle sigara içtikleri ve sigara içilmesi 
konusundaki tutum ve davranışları, matematik başarısıyla ilişkisi yeterince incelenmemiştir. Bu durum mevcut çalışmayı önemli kılmaktadır. Matematik öğretmen adaylarının sigara içmeye yönelik tutumlarının ve bu tutumlarını yordayan faktörlerin bilinmesi sigara kullanımını önleme veya azaltma konusunda önemli faydalar sağlayabilir. Bu noktadan hareketle mevcut araştırmanın amacı; öğretmen adaylarından, kronik sigara içicilerin sigara içme tutum davranışlarının kümelenme eğilimlerini belirlemek ve elde edilen kümelerin matematik başarısını yordama gücünü ortaya koymaktır.

\section{Yöntem}

\section{Araştırma Deseni}

Bu çalışmada “Çok Değişkenli İstatistiksel Yöntemlerden Kümeleme Yöntemi ve Kronik Sigara İçiciler Üzerine Bir Uygulama” isimli doktora tezinin (Çelik, 2004), örneklem gruplarından biri olan, matematik öğretmen adaylarının sigara içmeye yönelik tutum ve davranışlarına ilişkin verileri analiz edilmektedir. Araştırma, ilişkisel tarama modelindedir. Mevcut bu araştırmada sigara içmeyle ilgili bilgi, tutum ve davranışlar ile matematik başarısı arasındaki ilişkiyi belirten verilerin elde edilmesi noktasında ilişkisel tarama modeli tercih edilmiştir. "İlişkisel tarama modeli iki ve daha çok sayıdaki değişken arasındaki ilişkinin birlikte değişim varlığını veya derecesini belirlemeyi amaçlayan araştırma modelidir. Bu tür bir modelde, aralarında ilişki aranacak değişkenler ayrı ayrı sembolleştirilir” (Karasar, 2011, s. $81)$.

\section{Araştırma Grubu}

Araştırmanın çalışma grubunu, 2003-2004 akademik y1lı bahar döneminde Güney Doğu Anadolu Bölgesinde bulunan bir devlet üniversitesinin, eğitim fakültesi, matematik eğitimi anabilim dalında öğrenim gören, amaçlı örnekleme yöntemiyle seçilen 148 (41 kadın, 107 erkek) matematik öğretmen adayı/öğrenci oluşturmaktadır. Eğitim fakültesinde okuyan 
öğrenciler, geleceğin öğretmenleri olmaları açısından sigarayla mücadelede önemli bir kesimi oluşturmaktadırlar (Talay, Kurt ve Tuğ, 2008). Amaçlı örnekleme çalışmanın amacına bağlı olarak bilgi açısından zengin olayların/durumların seçilerek derinlemesine araştırma yapılmasına olanak sağlar (Büyüköztürk vd., 2012, s. 90). Bu çalışmada öğrencilerin sigara içmeye yönelik bilgi, tutum ve davranışları hakkında ayrıntılı bilgi almak söz konusu olduğundan amaçlı örnekleme yöntemi kullanılmıştır. Araştırmaya alınan öğretmen adaylarının yaş ortalamaları 18-26 yaş arasındadır.

\section{Veri Toplama Araçları}

Araştırmada veriler kişisel bilgi formu, sigara içme anketi ve matematik başarı puan ortalamaları aracılığıyla toplanmıştır. Kişisel Bilgi Formu: Araştırmacı tarafından hazırlanmış olan formda; öğrencilerin bazı sosyo-demografik özelliklerini (cinsiyet, yaş) ve sigara içmeyle ilgili kişisel özelliklerini belirleyen sorular (ilk sigaraya başlama yaşı, sigaraya başlamada etki eden faktörler, günde içilen sigara sayısı, kaç yıldır sigara içtikleri) vardır. Sigara İçme Anketi: Araştırmacı tarafından hazırlanmış olup öğrencilerin sigara içmeye yönelik bilgi, tutum ve davranışlarını belirlemeye yönelik 5'li Likert tipinde 24 ifadeden oluşmaktadır. Veri toplama aracı esas uygulama öncesinde uzman görüşüne sunulmuştur, ayrıca bir grup öğrenci üzerinde pilot çalışma olarak uygulanmıştır. Alınan dönütler yardımıyla ankete son hali verilmiştir. Maddeler; 1 "tamamen katılıyorum", 2 "bir kısmına katılıyorum", 3 "kararsızım", 4 "bir kısmına katılmıyorum" ve 5 "hiç katılmıyorum” şeklinde puanlanmıştır. Buna göre anketten alınabilecek en yüksek puan 120 en düşük puan ise 24'tür. Yüksek puan sigara içmeye yönelik olumlu duyguları temsil etmektedir. Esas uygulama sonucunda Cronbach alfa iç tutarlılık güvenirlik katsayısı .69 olarak hesaplanmıştır. Matematik Başarı Puan Ortalaması: Öğrencilerin Genel Matematik dersi yılsonu başarı puan ortalamasıdır. Öğrencilerin matematik 
başarı puan ortalamalarını belirlemek amacıyla araştırmacı tarafından, öğrenci otomasyon sistemi kayıtlarından alınmıştır.

\section{Verilerin Analizi}

Araştırmada sigara içme anketindeki maddeler X1, X2, .., X24 şeklinde kodlanmıştır. $\mathrm{Bu}$ maddeler Likert tipinde olduğundan standartlaştırma işlemi yapılmamış, değişkenler arasındaki uzaklıkların hesaplanmasında benzerlik/farklılık ölçümü olarak karesel öklid uzaklığı seçilmiş ve kümelenme eğilimlerinin belirlenmesi için aşamalı kümeleme yöntemlerinden, Ward bağlantı tekniği tercih edilmiştir. Aşamalı kümeleme yöntemleri özellikle küçük örneklemler (tipik olarak n<250) için uygun (Çokluk, Şekercioğlu ve Büyüköztürk, 2012) olan ve başlangıçta veri setindeki küme sayısının bilinmediği durumlarda kullanılmaktadır. Ward aşamalı kümeleme tekniği değişkenlerin kümelenmesinde, varyansı minumuma indiren ve optimum küme sayısını tahmin etmede kullanışlı bir tekniktir (Cryer ve diğg., 2001). Çalışmada öğrencilerin sigara içmeyle ilgili değişkenlerine ait kümelenme eğilimlerinin, matematik başarısının anlamlı bir yordayıcısı olup olmadığı Çoklu Regresyon Analizi yöntemiyle incelenmiştir. Bu noktada öğrencilerin sigara içme ile ilgili bilgi, tutum ve davranışlarına ait oluşan kümeler bağımsız (yordayan) değişken, matematik başarısı ise bağımlı (yordanan) değişken olarak alınmıştır. "Çoklu regresyon analizi, bağımlı değişkenle ilişkili olan iki ya da daha fazla bağımsız değişkene bağlı olarak bağımlı değişkenin tahmin edilmesiyle ilgili olan bir analiz yöntemidir” (Büyüköztürk, 2014, s. 95). Veriler SPSS 21.0 (Statistical Package for Social Sciences) paket programıyla analiz edilmiştir. Elde edilen sonuçlar tablolar ve dendogramlar halinde sunulmuştur.

\section{Bulgular}

Araştırmanın bu bölümünde sırasıyla, üniversite öğrencilerinin bazı sosyo-demografik özellikleri ve sigara içmeyle ilgili kişisel özelliklerinin betimsel istatistiklerine, sonra 
öğrencilerin sigara ile ilgili bilgi, tutum ve davranışlarının kümelenme eğilimlerine ve son olarak kümelenme eğilimlerinin matematik başarısını yordama gücüne ilişkin bulgulara yer verilmiştir.

Araştırma kapsamına alınan öğrencilerin bazı sosyo-demografik özellikleri ve sigara içmeyle ilgili kişisel özelliklerini belirleyen değişkenlere ait frekans, yüzde, ortalama değerleri hesaplanmıştır. Elde edilen bulgular Tablo 1'de gösterilmiştir.

Tablo 1. Öğrencilerin bazı kişisel özelliklerine ait betimsel istatistikler

\begin{tabular}{llcc}
\hline Değişkenler & & Frekans (f) & Yüzde (\%) \\
\hline Cinsiyet & Kadın & 41 & 27.7 \\
& Erkek & 107 & 72.3 \\
\hline İlk sigara içme yaşı & $18-20$ yıl & 24 & 16.3 \\
& $21-23$ yıl & 94 & 63.5 \\
& $24+$ yıl & 30 & 20.2 \\
& $\bar{X} \pm$ S.s $=15.98 \pm 2.71$ yıl & & \\
\hline Sigara sayıs1 & $1-9$ adet & 12 & 8.1 \\
& $10-18$ adet & 43 & 29.1 \\
& $19-27$ adet & 72 & 48.6 \\
& $28+$ adet & 21 & 14.2 \\
\hline Sigara içme süresi & $\bar{X} \pm$ S.s $=19.22 \pm 8.43$ adet & & \\
& $1-6$ yıl & 85 & 57.5 \\
& $7-12$ yıl & 59 & 39.9 \\
& $13+$ yll & 4 & 2.8 \\
\hline Etkili olan çevre değişkenleri & X \pm S.s $=6.56 \pm 4.16$ yll & & \\
& Anne-baba & 6 & 4.1 \\
& Arkadaşlar & 112 & 6.1 \\
& Bilmiyorum & 9 & 14.2 \\
\hline
\end{tabular}

Tablo 1'e göre sigara içen öğrencilerin \%27.7'si kadın \%72.3’ü erkektir. Öğrencilerin ilk sigaraya başlama yaş ortalaması $15.89 \pm 2.71$ yıldır ve \%63.5'i ilk sigarayı $21-23$ yaşlarında, \%20.2'si 24 ve üstü yaşlarda, \%16.3'ü 18-20 yaşları arasında başlamıştır. Günde içtikleri ortalama sigara sayıs1 19.22 8.43 adettir ve \%48.6's1 günde 19-27 adet, \%29.1'i 10-18 adet, $\% 14.2$ 'si 28'den fazla ve \% 8.1'i 1-9 adet arasında sigara içmektedir. Bununla birlikte öğrencilerin ortalama sigara içme süresi $6.56 \pm 4.16$ yıldır ve $\% 57.5$ 'i 1-6 yıldır, \%39.9’u 7-12 yıldır ve \% 2.8'i 13 yıldan fazla bir süredir sigara içmektedirler. Öğrencilerin sigara 
içmelerinde birinci derecede etki eden çevresel faktör \%75.7 oranıyla "arkadaşlar" olup, bunu “anne-baba (\%4.1)", "bilmiyorum (\%6.1)" ve "diğer (\%14.2)” faktörler izlemektedir.

Öğrencilerinin sigara içme ile ilgili bilgi, tutum ve davranışlarına ait değişkenlerin (X1, X2,..,X24) kümelenme eğilimlerini belirlemek amacıyla yapılan aşamalı kümeleme analizinde, karesel öklid uzaklığı seçilmiş ve Ward aşamalı kümeleme tekniği uygulanmıştır. Elde edilen birleştirme planı Tablo 2'de verilmiştir.

Tablo 2. Sigara içme değişkenlerine ait birleştirme planı

\begin{tabular}{|c|c|c|c|c|c|c|}
\hline \multirow[t]{2}{*}{ Aşama } & \multicolumn{2}{|c|}{ Birleştirilmiş küme } & \multirow[t]{2}{*}{ Katsayılar } & \multicolumn{2}{|c|}{ İlk görülen küme aşaması } & \multirow{2}{*}{$\begin{array}{c}\text { Sonraki } \\
\text { aşama }\end{array}$} \\
\hline & Küme 1 & Küme 2 & & Küme 1 & Küme 2 & \\
\hline 1 & 2 & 18 & 48.50 & 0 & 0 & 2 \\
\hline 2 & 1 & 2 & 102.66 & 0 & 1 & 3 \\
\hline 3 & 1 & 6 & 194.75 & 2 & 0 & 4 \\
\hline 4 & 1 & 3 & 299.60 & 3 & 0 & 6 \\
\hline 5 & 21 & 24 & 406.60 & 0 & 0 & 7 \\
\hline 6 & 1 & 5 & 519.33 & 4 & 0 & 12 \\
\hline 7 & 4 & 21 & 664.33 & 0 & 5 & 8 \\
\hline 8 & 4 & 10 & 845.58 & 7 & 0 & 13 \\
\hline 9 & 19 & 20 & 1058.58 & 0 & 0 & 10 \\
\hline 10 & 14 & 19 & 1294.25 & 0 & 9 & 20 \\
\hline 11 & 22 & 23 & 1531.25 & 0 & 0 & 15 \\
\hline 12 & 1 & 15 & 1773.77 & 6 & 0 & 13 \\
\hline 13 & 1 & 4 & 2022.39 & 12 & 8 & 20 \\
\hline 14 & 8 & 11 & 2299.89 & 0 & 0 & 18 \\
\hline 15 & 12 & 22 & 2583.56 & 0 & 11 & 17 \\
\hline 16 & 7 & 16 & 2872.06 & 0 & 0 & 21 \\
\hline 17 & 12 & 13 & 3161.89 & 15 & 0 & 22 \\
\hline 18 & 8 & 9 & 3510.39 & 14 & 0 & 19 \\
\hline 19 & 8 & 17 & 3906.14 & 18 & 0 & 21 \\
\hline 20 & 1 & 14 & 4340.60 & 13 & 10 & 23 \\
\hline 21 & 7 & 8 & 4836.69 & 16 & 19 & 22 \\
\hline 22 & 7 & 12 & 5646.65 & 21 & 17 & 23 \\
\hline 23 & 1 & 7 & 7886.75 & 20 & 22 & 0 \\
\hline
\end{tabular}

Tablo 2'deki verilerden öğrencilerin sigara içmeyle ilgili değişkenleri incelendiğinde, her aşamada hangi değişkenlerin birleştiği ve birleşen değişkenlerin katsayıları detaylarıyla görülmektedir. Birinci aşamada birleştirilmiş küme sütunu incelendiğinde Küme 1'deki X2 değişkeni (madde) ile Küme 2'deki X18 değişkenin (madde) birbirine en yakın gözlemler 
olduğu ve 48.50 katsayısında birleşmiştir. X2 ve X18 değişkenleri ikinci aşamada X1 değişkeni ile birleşerek ilk kümeyi oluşturmuştur. Bu birleşme planına ait dendogram grafiği Şekil 1'de gösterilmiştir.

Şekil 1'deki dendogram, sigara içme ile ilgili değişkenlerin, tek bir kümede yer alana kadar her adımda değişkenlerin nasıl birleştirildiğini grafik olarak göstermektedir. Ward's bağlantı tekniği sonucunda elde edilen dendogramda, öğrencilerin sigara içme ile ilgili değişkenlerinin C1, C2 ve C3 şeklinde üç kümede toplandığg görülmektedir. C1 kümesinde 14 değişken (X1, X2, X3, X4, X5, X6, X10, X14, X15, X18, X19, X20, X21, X24), C2 kümesinde 4 değişken $(\mathrm{X} 12, \mathrm{X} 13, \mathrm{X} 22, \mathrm{X} 23)$ ve son olarak C3 kümesinde 6 değişken (X7, X8, X9, X11, $\mathrm{X} 16, \mathrm{X} 17)$ yer almıştır.

C1 kümesindeki değişkenler; (X1)Sigara sağlığa zararlıdır, (X2)Toplumun sigara ve zararları hakkında aydınlatılması gerekir, (X3)İnsanların toplu olarak bulundukları kapalı ortamlarda sigara içilmemelidir, (X4)Sigara içmiyor olmanın memnun edici yanı vardır, (X5)Teklif edilen sigara, sigara içme oranını artırır, (X6)Sigaranın rahatsız edici unsurlarından birisi sigara dumanıdır değişkenleri vardır, (X10)Sigara içmiyor olsaydım, başlamayı düşünmezdim, (X15)Sigara dumanını içime çekmeyi çok severim, (X18)Sigara ağız ve diş sağlığımı olumsuz yönde etkiler, (X21)Sigara içmeseydim şu anda daha sağlıklı olurdum ve (X24)Keşke sigara kullanmasaydım, (X14)Sigara içmek ya da içmemek bana bağlıdır, (X19)Sigara içmek tansiyonu yükseltir ve (X20)Sigara içme ile ilgili uyarıları önemsememenin mantıksız olduğunu düşünüyorum şeklindedir. 


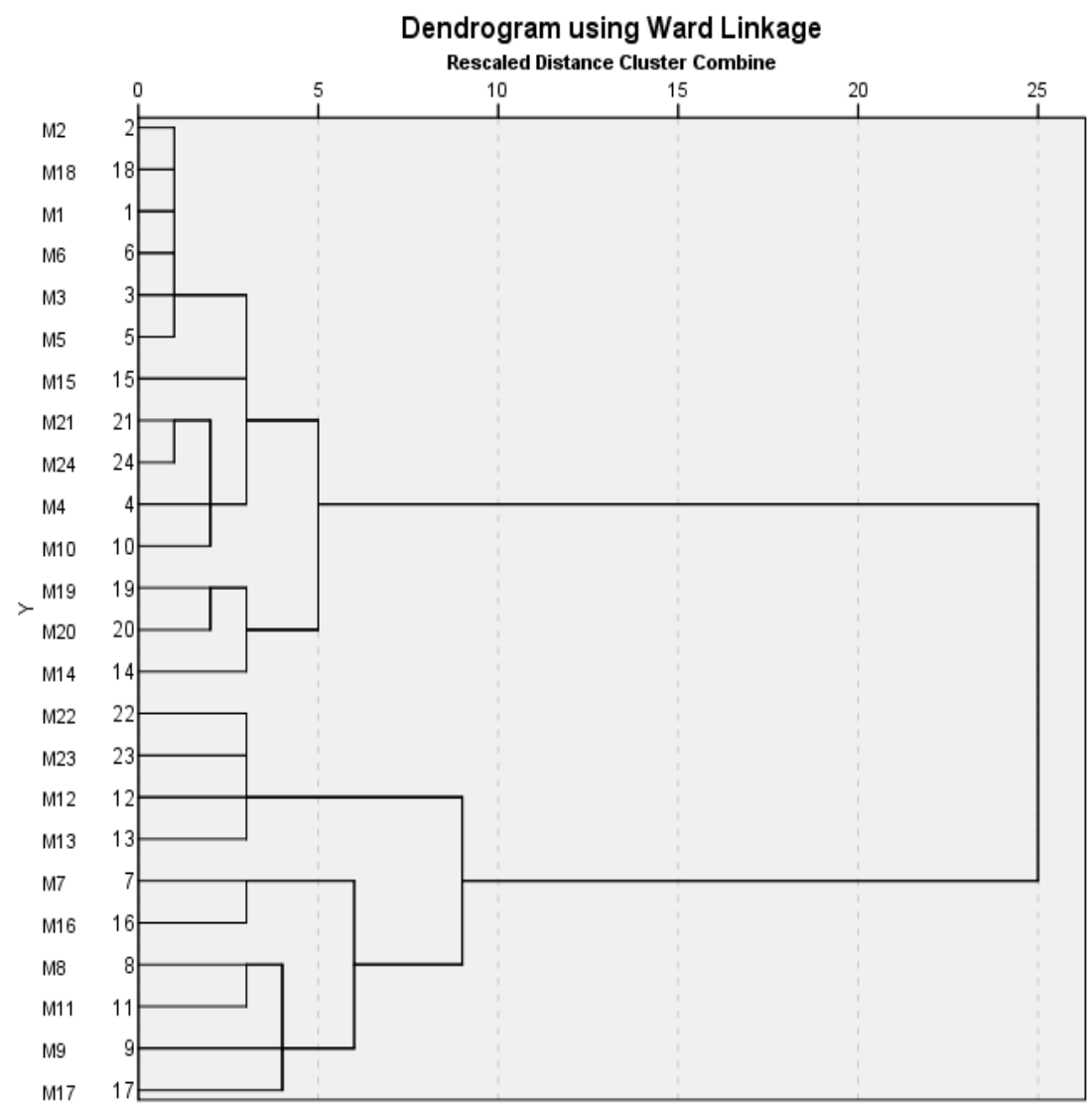

Şekil 1. Sigara içme değişkenlerine ait dendogram grafiği

C2 kümesinde (X12)Sigarayı bırakırsam kilo alacağıma inanıyorum, (X13)Sigarayı farkında olmadan otomatik olarak yakarım, (X22)İşimi daha iyi yapmak ve konsantrasyonumu arttırmada sigara önemli bir etkendir ve (X23)Sigarayı bırakırsam etrafımdakilere karşı daha sinirli ve kırıcı olurum değişkenleri bulunmaktadır.

C3 kümesinde ise (X7)Sigara paketleri üzerindeki "sigara sağlığa zararlıdır” uyarısı sigara tüketiminin azaltılmasında etkilidir, (X16)Sigara içmesem ellerimi nereye koyacağımı bilemem, X8)Bulunduğum ortamlarda sigara içilmesinden rahatsız olurum, (X9)Sigara reklamlarının özendirici yanı vardır, (X11)Doktorum bana sigarayı bırak derse bırakırım ve (X17)Doktorlar sigara içmeseydi, söylediklerini daha inandırıcı bulurdum değişkenleri yer almıştır. 
Öğrencilerin sigara içme ile ilgili değişkenlerine ait kümelenme eğilimleri neticesinde oluşan C1, C2 ve C3 kümelerinin matematik başarısını yordama gücünü hesaplamak için çoklu regresyon analizi yapılmıştır. Elde edilen bulgular Tablo 3’te verilmiştir.

Tablo 3. Matematik başarısının yordanmasına ilişkin çoklu regresyon analizi sonuçları

\begin{tabular}{clccccccc}
\hline Model & $\begin{array}{c}\text { Yordayıcı } \\
\text { Değisskenler }\end{array}$ & B & $\begin{array}{c}\text { Standart } \\
\text { hata }\end{array}$ & $\boldsymbol{\beta}$ & $\mathbf{t}$ & $\mathbf{p}$ & İkili r & Kısmi r \\
\hline 1. & Sabit & 148.22 & 10.60 & - & 13.97 & .00 & - & - \\
2. & C1 & -9.08 & 2.40 & -.22 & -3.78 & .00 & $-.33 *$ & -.30 \\
3. & C2 & -9.32 & 1.01 & -.53 & -9.27 & .00 & $-.62^{*}$ & -.61 \\
4. & C3 & -8.08 & 1.46 & -.32 & -5.52 & .00 & $-.46^{*}$ & -.42 \\
\hline
\end{tabular}

Bağımlı Değișken: Matematik Başarısı

$\mathrm{R}=.74, \quad \mathrm{R}^{2}=.55$

$\mathrm{F}_{(3,144)}=57.52, \quad \mathrm{p}=.000$

Tablo 3'e göre C1, C2 ve C3 birlikte, öğrencilerin matematik başarı puanları arasında orta düzeyde ve anlamlı bir ilişki bulunmuştur. $\mathrm{R}=.74, \mathrm{R}^{2}=.55, \mathrm{p}<.01$ 'dir. İlgili kümeler birlikte, matematik başarısındaki toplam varyansın yaklaşık \%55'ni açıklamaktadır. Ayrıca Tablo 3'ten standardize edilmiş regresyon katsayısına göre, yordayıcı değişkenlerin matematik başarısı üzerindeki göreli önem sıras1; C2, C3 ve C1'dir. Regresyon katsayılarının anlamlılığına ilişkin t-testi sonuçlarına göre $\mathrm{C} 1(\mathrm{~B}=-9.08 ; \mathrm{p}<.01), C 2(\mathrm{~B}=-9.32 ; \mathrm{p}<.01)$ ve $\mathrm{C} 3$ $(\mathrm{B}=-8.08 ; \mathrm{p}<.01)$ kümelerinin matematik başarısının anlamlı yordayıcısı olduğu görülmektedir. Katsayıların negatif olduğu göz önüne alındığında sigaraya yönelik olumlu tutumların matematik başarısının düşük olması ile ilişkili olduğu söylenebilir. Regresyon analizi sonuçlarına göre matematik başarısının yordanmasına ilişkin matematiksel model "Matematik Başarısı=148.22-9.08(Küme 1)- 9.32(Küme 2)-8.08(Küme 3)" ş̧eklindedir.

\section{Tartışma Sonuç ve Öneriler}

$\mathrm{Bu}$ araştırmada matematik eğitimi anabilim dalında okuyan öğrencilerin sigara içme tutum ve davranışlarına yönelik değişkenlerin tanımlayıcı istatistikleri hesaplanmış ve 
kümelenme eğilimleri Ward bağlantı tekniği kullanılarak belirlenmiştir. Oluşan kümelerin matematik başarısını yordama gücü çoklu regresyon analizi yoluyla belirlenmiştir.

Üniversiteye başlayan öğrencilerde aile ve çevreden uzaklaşmanın ve nispeten özgür bir ortamda bulunmanın etkisiyle sigara içme alışkanlığı yaygınlaşmaktadır (Çivi ve Şahin, 1991). Alan yazında sigara içenlerin yaklaşık \%80'inin sigaraya 18 yaşın altında başladığ (Doğan ve Ulukol, 2010) belirtilmiştir. Ayrıca bazı çalışmalarda öğrencilerin yaş grubuna göre sigara kullanma davranışları arasında anlamlı bir fark olduğu, 21 yaş ve üzerindeki öğrencilerin sigara kullanma davranışlarının daha yüksek olduğu (Duran ve Gözeten, 2017) görülmüştür. Diğer bir çalışmada ise üniversite öğrencilerinin \%30.7'sinin sigarayı ilk kez 18 yaş ve üzerinde denediği belirtilmiştir (Turhan ve diğ., 2011). Bireylerde 10-19 yaşlar arası ergenlik dönemi olarak bilinmektedir. Bu dönemdeki öğrenciler arasında arkadaşlık büyük önem kazanmakta ve yetişkinler taklit edilmektedir (Kulaksızoğlu, 2001). Bu araştırmada matematik

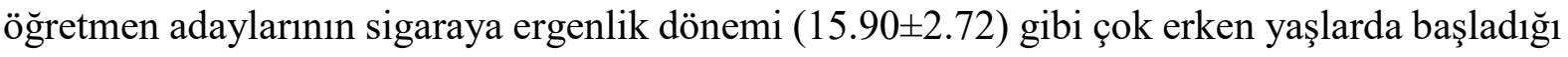
ve altı yıldır düzenli olarak sigara içtikleri sonucuna varılmıştır. Ülkemizde yapılan çalışmalar ortalama sigara içmeye başlama yaşının 16-19 yaş arasında değiştiğini göstermiştir (Akfert, Çakıcı ve Çakıcı, 2009; Dağcı, Dinç ve Özcan, 1998; Korkmaz ve diğ., 2013; T.C. Sağlık Bakanlı̆̆1, 2014).

Sigaranın önemli sağlık sorunlarına yol açtığı bilinmesine rağmen bağımlılık haline gelen bu alışkanlık gittikçe artmaktadır. ABD'de sigara tüketimi 1981'den 2000'e kadar \%32.8 oranında azalırken Türkiye'de 1984-2000 döneminde sigara tüketimi\%89 oranında artmış (Soydal ve Ergüder, 2002), 2000 yılından sonra gerçekleştirilen tütün kontrolü çalışmaları ile azalmaya başlamıştır (Kamışlı ve diğ., 2017). Bu araştırma sonucunda ulaşılan diğer önemli bulgu öğrencilerin yarısından fazlasının bir paket ve bir paketten daha çok sigara içtiğidir. KYTA Türkiye 2012 raporunda halen sigara içen bireylerin günde ortalama 19.2 sigara içtiği 
(T.C. Sağlık Bakanlığı, 2014), sigara bağımlılığı ile ilgili yapılmış çalışmalarda, üniversite öğrencilerinin sigara içme oranının yüksek çıktığı saptanmıştır (Çelepkolu ve dĭg., 2014; Çilingir, Hintistan ve Öztürk, 2012; Karadă̆ ve diğ., 2011; Mayda ve diğg., 2010). Bu noktada geleceğin öğretmenleri olacak ve çocuklarımıza model oluşturacak öğretmen adaylarına yönelik üniversiteler de sigaranın zararları konusunda farkındalık kazandırılması adına etkinlikler düzenlenmeli, sigarayı azaltmaya veya bırakmaya yönelik programların oluşturulmasına gereksinim duyulmaktadır.

Sigara içme öğrenciler açısından yetişkinlerden ve arkadaş çevrelerinden model olarak alınan bir problem çözme ve stresi azaltma davranışı olarak benimsenmektedir (Erbaydar, Avc1 ve Altay, 2003). Bu çalışmada matematik öğretmen adaylarının sigara içmelerinde birinci derecede etki eden faktörün yakın çevre olduğu dikkat çeken diğer bir bulgudur. Alan yazında konu ile ilgili yapılmış çalışmalarda benzer sonuçlara rastlanmaktadır. Bu çalışmalarda, yakın arkadaşının sigara içme durumu öğrencilerin sigara içmesinde önemli bir faktör olduğu saptanmış (Atlam ve Yüncü, 2017; Doğan, 2003) ve yetişkinin sigaraya başlamasında; arkadaşların sigara içmesinin (Doğan ve Ulukol, 2010; Graham, Marks ve Hansen, 1991; Yazıcı ve Şahin, 2005), aile fertlerinin sigara içmesinin etkili olduğu bulunmuştur (Shaw, Mitchell ve Darling, 2000). Bu bulgular çalışmamızın sonuçlarıyla örtüşmektedir.

Araştırmada matematik öğretmen adaylarının sigara içmeyle ilgili değişkenlerine uygulanan kümeleme analizi neticesinde üç küme oluşmuştur. C1 kümesi, bireylerin sigara içmeme konusunda bilgilendirilmesi gerekliliği, sigara içmemenin memnun edici yanları ve sağ lığa zararlarına ilişkin algılanan sağlık risklerini yansıtan değişkenleri içermesinden dolayı "Sigara içmeye ilişkin bilişsel farkındalık” olarak adlandırılmıştır. Üniversite öğrencilerinin entelektüel düzeyi yüksek olduğu için sigara içmeyle ilgili bilişsel değerlendirmelerini ortaya koymak anlamlıdır (Yazıcı, 2007). C2 kümesi, sigarayı bırakma durumunda kilo alma, işini 
yapamama ve çevredekilere karşı sinirli olabileceğine dair inançların yanında aslında sigaranın artık bir alışkanlık olduğu için farkında olmadan yaktığına ait bağımlılık durumlarını yansıttığından “Sigara bağımlılığı ve etkileri” kümesi adını almıştır. Konan (2012) sigara içen öğretmenler üzerinde yaptığı çalışmada matematik öğretmenlerinin bağımlık düzeyini diğer öğretmenlere göre daha düşük bulmuştur. Başka bir çalışma matematik öğretmenlerinin de içinde bulunduğu bir grup öğretmenin sigara içme davranışları araştırılmış ve öğretmenlerin neredeyse yarısının sigara içme alışkanlığının bulunduğu ve ilgili alışkanlığın branş değişkeni açısından anlamlı farklılık göstermediği tespit edilmiştir (Şahin ve Tunç, 2008). Son olarak C3 kümesi sigara paketleri üzerindeki uyarıların sigarayı bırakma üzerindeki olumlu etkileri, sigara dumanından pasif içici olarak duyulan rahatsızlık, çevrenin ve özellikle doktorların sigarayı bırakma konusundaki uyarılarıyla ilgili değişkenlere sahip olduğundan "Sigaraya yönelik algısal uyarılar ve çevre" olarak adlandırılmıştır. Sigarayla ilgili tutum ve davranışların değerlendirilmesi ya da sigara içme şekillerinin kümelenme eğilimlerinin araştırılması amacıyla yapılan araştırmalar, kümeleme yöntemlerinin, bu türdeki yapılar için başarılı/anlamlı sonuçlar verdiğini göstermiştir. Creyer ve diğ., (2001) çalışmalarında sigara içenlerin tutumlarını ve davranış özelliklerini belirlemek amacıyla kümeleme analizini kullanmış ve sigara içenlerin, isteksiz içiciler, yumuşak başlı içiciler ve dik başlı içiciler şeklinde üç kümede toplandığını bulmuşlardır. Ayrıca Kerby, Brand ve John (2003) yaptıkları çalışmada, öğrencilerin sinirlenme/öfkelenme tiplerinin belirlenmesi ve bunun sigara içenlere uyarlanması amacıyla ward kümeleme yöntemini kullanmışlarıdır. Kümeleme analizi neticesinde temel öfke tiplerinin, düşük tepki, uyarlamalı tepki, içsel ve dişsal tepki olmak üzere dört küme oluşturduğunu tespit etmişlerdir.

Araştırmada yapılan çoklu regresyon analizi neticesinde matematik öğretmen adaylarının matematik başarısı bağımlı değişken olarak alınıp, kümeleme analizi sonucu elde 
edilen üç kümeyi yordama düzeyi hesaplanmıştır. İlgili üç küme birlikte, matematik başarısındaki toplam varyansın yaklaşık \%55'ni açıklamıştır. Ayrıca yordayıcı kümelerin matematik başarısı üzerindeki göreli önem sırası; "Sigara bağımlılığı ve etkileri”, "Sigaraya yönelik algısal uyarılar ve çevre" ve "Sigara içmeye ilişkin bilişsel farkındalık" kümeleridir. Buradan öğrencilerin sigara içme ile ilgili bilgi tutum ve davranışlarına ilişkin kümelenme eğilimlerinin matematik başarısı üzerinde etkili olabildiği söylenebilir. Kaşkır (2012) çalışmasında sigara içen öğrencilerin sigara içme alışkanlıklarını etkileyebilecek değişkenleri belirlemek için logaritmik doğrusal analiz yöntemini uygulamıştır. Çalışması sonucunda, okuldaki başarı durumunun ve sigaranın sağlığa zararlarının birlikte, sigara kullanma niyetini etkilediğini belirlemiştir. Ayrıca okuldaki başarı durumunun sigara içilen yıl sayısında etkili bir faktör olduğunu bulmuştur. Bu bulgu çalışmamızın sonuçlarıyla benzerlik göstermektedir. Aksini savunan bazı çalışmalarda, ders başarısının sigara ile ilişkili davranışlara etkisi incelenmiştir. Bu çalışmalarda sigara içmeyen öğrencilerin sigara içenlere göre daha başarılı olduğu (Doğan, 2003), okul başarısı yüksek olanların sigara içme sıklığının daha düşük olduğu (Ritchey, Reid ve Hasse, 2001) belirlenmiştir.

$\mathrm{Bu}$ çalışmada çok değişkenli istatistik yöntemlerden biri olan kümeleme analizi, matematik öğretmen adaylarının sigara içmeyle ilgili değişkenlerine ait çözümlemede benzer, ilginç ve başarılı kümeler oluşturmuş, değerlendirmelerde kolaylık sağlamıştır. Oluşan kümelerin matematik öğretmen adaylarının matematik başarısını yordama düzeylerine ilişkin sonuçlar, öğretim faaliyetlerinde daha etkili öğrenmeler gerçekleştirme ve başarıyı geliştirmede söz konusu tutum ve davranışları tahmin etmede katkı sağlayabilir. Bu çalışma her ne kadar matematik öğretmen adaylarının sigara içmeye yönelik tutum ve davranışlarına odaklansa da elde edilen her bir kümedeki özellikler matematik başarısı için değerlendirilebilecek faktörler olarak düşünülebilir. Bu kapsamda benzer çalışma yapacak 
araştırmacıların bu özellikleri göz önünde bulundurmaları önerilebilir. Ayrıca kümeleme analizi konusunda matematik eğitimi alanında yapılmış herhangi bir çalışmaya rastlanmamıştır. $\mathrm{Bu}$ yönüyle önem kazanan çalışmanın ilgili alana katkı sağlayacağı düşünülmektedir. Diğer taraftan araştırmaya alınan matematik öğretmen adaylarına veri toplama aracı olarak yalnızca sigara içmeyle ilgili bir anket uygulanmış ve elde edilen verilerin matematik başarısıyla ilişkisi değerlendirilmiştir. $\mathrm{Bu}$ noktada ileride kümeleme analizi konusunda çalışma yapacak araştırmacılara, matematik başarısına etkisi olduğu düşünülen matematik tutum ve kaygısı gibi farklı veri toplama araçları kullanarak, daha geniş örneklemler ve yaklaşımları dikkate alarak çalışmalar yapmaları önerilebilir.

\section{Makalenin Bilimdeki Konumu}

Matematik ve Fen Bilimleri Eğitimi, Matematik Eğitimi Ana Bilim Dalı

\section{Makalenin Bilimdeki Özgünlüğü}

Türkiye'de sigara ile ilgili yapılmış çalışmalarda sigara içme sıklığı ortaya konmakla birlikte, insanların hangi nedenlerle sigara içtikleri ve sigara içmeye yönelik tutum ve davranışlarının, matematik başarısıyla ilişkisi yeterince incelenmemiştir. Çalışma bu noktada özgün bir değere sahiptir. Ayrıca alan yazında matematikte akademik başarı konusunda toplanmış verilere çok değişkenli istatistiksel yöntemlerden birisi olan kümeleme analizinin uygulanması ve optimum kümeler elde etmede önemli bir yere sahip olan ward bağlantı tekniğinin kullanılması da çalışmamızın özgünlüğüne katkı sağlamaktadır. Bunun yanında öğrencilerin sigara içmeyle ilgili davranışlarının kümelenme eğilimlerinin çoklu regresyon analizi yöntemiyle matematik başarısını yordama gücünün belirlenmesi de diğer önemli bir özgün değerdir. 
ISSN: 1305-020

\section{Kaynaklar}

Akfert, S.K., Çakıcı, E. ve Çakıcı, M. (2009). Üniversite Öğrencilerinde Sigara-Alkol Kullanımı ve Aile Sorunları İle İlişkisi. Anatolian Journal of Psychiatry, 10, 40-47.

Akhan, Ş. ve Bindak, R. (2017). Bazı Kişisel Değişkenlerin Ortaokul Öğrencilerinin Matematik Başarısı Üzerindeki Etkisi: Bir Regresyon Modeli. Ihlara Eğitim Araştırmaları Dergisi, 2(2), 05-17

Altıntaş, K.H., Adıgüzel, M.O., Koç, A.M., Aralov, B., Yiğit, E. ve Orhan E. (2008). Bir Grup Öğrencinin Sigara İçme Davranışları ve Sigaranın Sağlık Etkileri İle İlgili Bilgileri. Bă̆ımlılık Dergisi, 9(3), 107-113.

Altun, M. (2010). İlköğretim 2. Kademe (6,7, 8. sinıflarda) Matematik Öğretimi. Bursa Aktüel Alfa Akademi

Atlam, D. H. ve Yüncü, A. (2017). Üniversitesi Öğrencilerinde Sigara, Alkol, Madde Kullanım Bozukluğu ve Ailesel Madde Kullanımı Arasındaki İlişki. Klinik Psikiyatri, 20:161-170 Baykul, Y. (2009). Illköğretimde Matematik Öğretimi 6-8. Sinıflar. Ankara: Pegem Akademi Bilir, N. ve Yıldız, A. N. (2008). Çalışma Hayatı ve Sigara (Sigarasız İşyerleri). Ankara: Klasmat Matbaac1lik

Büyüköztürk, Ş., Kılıç Çakmak, E., Akgün, Ö. E., Karadeniz, Ş. ve Demirel, F. (2012). Bilimsel Araştırma Yöntemleri (11. Baskı). Ankara: Pegem Akademi Publishing

Büyüköztürk, Ş. (2014). Sosyal Bilimler İçin Veri Analizi El Kitabı (18. baskı). Ankara: Pegem Akademi Yayıncılık.

Çakmak, Z. (1999). Kümeleme Analizinde Geçerlilik Problemi ve Kümeleme Sonuçlarının Değerlendirilmesi. Dumlupınar Üniversitesi Sosyal Bilimler Dergisi, Say1 3, 187-205

Çalışkan, Ş. (2015). Üniversite Öğrencilerinin Sigara Kullanımını Etkileyen Faktörler (Ekonometrik Bir Yaklaşım). Uşak Üniversitesi Sosyal Bilimler Dergisi, 8(2), 23-48 
Çelepkolu, T., Atlı, A., Palancı, Y., Yılmaz, A., Demir, S., İbiloğlu, A.O. ve Ekin, S. (2014). Sigara Kullanıcılarda Nikotin Bağımlılık Düzeyinin Yaş ve Cinsiyetle İlişkisi: Diyarbakır Örneklemi. Dicle Tıp Dergisi, 41, 712-716.

Çelik, H. C. (2004). Çok değişkenli istatistiksel yöntemlerden kümeleme yöntemi ve kronik sigara içiciler üzerine bir uygulama (Yayımlanmamış Doktora Tezi). Dicle Üniversitesi, Diyarbakır.

Çilingir, D., Hintistan, S. ve Öztürk, H. (2012). Sağlık Yüksekokulu Öğrencilerinin Sigara Kullanma Alışkanlıkları ve Etkileyen Faktörler. Gümüşhane Üniversitesi, Sağlık Bilimleri Dergisi, 1(2), 69-85.

Çivi, S. ve Şahin, T.K. (1991). Selçuk Üniversitesi Tıp Fakültesi ve Sağlık Hizmetleri Meslek Yüksek Okulu Öğrencilerinin Sigara Konusundaki Bilgi Tutum ve Davranışları. Aile ve Toplum, 1, 49-52.

Çokluk, Ö., Şekercioğlu, G. ve Büyüköztürk, Ş. (2016). Sosyal Bilimler Iç̧in Çok Değişkenli Istatistik: SPSS ve LISREL Uygulamaları. Ankara: Pegem Akademi Yayıncılık.

Cryer, P.C., Saunders, J., Jenkins, L.M., Neale, H., Cook, A.C. ve Peters, T.J. (2001). Clusters within a General Adult Population of Alchol Abstainers. International Journal of Epidemiology, 30, 756-765

Dağc1, T., Dinç, G. ve Özcan, C. (1998). Celal Bayar Üniversitesi Öğrencilerinin Sigara Kullanma Sıklığı ve Kullanımını Etkileyen Faktörler. Solunum Hastalıkları, 9, 607617.

Doğan, D. G. ve Ulukol, B. (2010). Ergenlerin Sigara İçmesini Etkileyen Faktörler ve Sigara Karşıtı İki Eğitim Modelinin Etkinliği. İnönü Üniversitesi Tıp Fakültesi Dergisi, 17(3), $179-185$ 
Doğan, D. G. (2003). Ergenlerin Sigara İçmesini Etkileyen Faktörler ve Sigara Karşıtı Eğitim Modellerinin Etkinliğinin Saptanması (Yayımlanmamış doktora tezi). Ankara Üniversitesi, Ankara.

Duran, S. ve Gözeten, A. (2017). Üniversite Öğrencilerinde Sigara İçme Davranışı, Yalnızlık ve Stresle Baş Etme Biçimleri Arasındaki İlişkinin İncelenmesi. Bozok Tıp Dergisi, $7(1), 1-7$

Emekdar, G., Çıtı1l, R., Önder, Y., Bulut, Y.E., Yaşayancan, Ö., Kazancı, N. Ö., Sönmezgöz, E. ve Eğri, M. (2017). Tokat İli Ortaokul ve Lise Öğrencilerinde Sigara İçme Prevalansı ve Etkileyen Faktörler. Journal of Contemporary Medicine, 7(1), 58-66

Erbaydar, T., Avcı, S. ve Altay, G. (2003). Öğretmenlerin Okul Ortamında Sigara İçilmesi ve Öğrencilerin Sigara Kullanımı Konusuna Yaklaşımları. M.Ü. Atatürk Eğitim Fakültesi Ĕ̈itim Bilimleri Dergisi, 17, 63-74

Ertem-Akbaş, E. (2018). Öğretmenlerin bakış açısıyla ilkokulla başlayan matematik korkusunun nedenlerinin ve çözüm önerilerinin incelenmesi. International e-Journal of Educational Studies (IEJES), 2(3), 12-25.

Everitt, B. S., Landau, S. ve Leese, M. (2001). Cluster Analysis (Fourth Edition). London: Arnold Publisher.

Everitt, B. S. (1995). Commentatory: Classification and Cluster Analysis. British Medical Journal, Vol: 311, 535-536.

Everitt, B. (1974). Cluster Analysis. London: Heinemann Educational Books Ltd.

Graham, J. W., Marks, G. ve Hansen, W. B. (1991). Social Influence Processes Affecting Adolescent Substance Use. Journal of Applied Psychology, 76(2), 291- 298.

Gürsoy, U. T. Ş. (2009). Veri Madenciliği ve Bilgi Keş̧i. Ankara: Pegem Akademi 
Johnson, R.A. ve Wichern, D.W. (2002). Applied Multivariate Statistical Analysis (5th ed.). New Jersey Prentice Hall, Inc.

Kamışl1, S., Yüce, D., Küçükçoban, Ş., Hayran, M., Kılıçkap, S., Çelik, İ. ve Erman, M (2017). Bir Sigara Bırakma Polikliniğinde Uygulanan Psikoeğitimsel Sigara Bırakma Programının Etkinliği. Anadolu Hemşirelik ve Sağlık Bilimleri Dergisi, 20(4), 234-242 Karasar, N. (2011). Bilimsel Araştırma Yöntemi. Ankara: Nobel Yayınları

Karadağ, M., Karadağ, S., Ediz, B. ve Işık, E.S. (2011). Nikotin Bağımlılığın Sigarayı Bırakmadaki Etkisi. Yeni Tıp Dergisi, 29: 27-31.

Kaşkır, F. (2012). Logaritmik Doğrusal Modeller ve Uygunluk Analizinin Birlikte Kullanımı: Lise Öğrencilerinin Sigara İçme Alışkanlıklarına Uygulanması (Yayımlanmamış Yüksek Lisans Tezi). Eskişehir Osmangazi Üniversitesi, Eskişehir.

Kerby, D.S., Brand, M.W. ve John, R. (2003). Anger Types and the use of Cigarettes and Smokeless Tabocco Among Native American Adolescents. Preventive Medicine, 3(5), $485-491$.

Konan, N. (2012). İlköğretim Okulu ve Lise Öğretmenlerinin Sigara İçme Alışkanlıkları. Sosyal Bilimler Dergisi, 2(4), 74-98

Korkmaz, M., Sıdıka, E., Özkahraman, Ş., Duran, E.T., Uslusoy, E.Ç, Orak, S. ve Orhan, H. (2013). Süleyman Demirel Üniversitesi Öğrencilerinin Tütün Mamulleri Alkol Kullanımı Durumları ve Sigaraya Yaklaşımları. S.D.Ü. Tıp Fakültesi Dergisi, 20(2), $34-42$

Kulaksızoğlu, A. (2001). Ergenlik Psikolojisi. İstanbul: Remzi Kitapevi

Mayda, A.S., Gerçek, Ç.G., Gümüş, G., Demir, S., Deniz, M., Pürücü, Z.P., Konuk, M., Türkmaya, M. ve Taner, H. (2010). Düzce Üniversitesi Orman Fakültesi Öğrencilerinde 
Sigara, Alkol ve Madde Kullanımı Sıklığı ve Kullanmaya Başlama Nedenleri. Düzce Tip Dergisi, 12(3), 7-14.

McLeod, D. B. (1992). Research on affect in mathematics education: a reconceptualization. In D. A. Grouws (Ed.), Handbook of research on mathematics teaching and learning (pp. 575-596). New York: Macmillan.

Mucha, H.J. ve Sofyan, H. (2003). Cluster analysis. http://www.mdtech.de web adresinden 6 Haziran 2003 tarihinde erişildi.

Özcebe, H. (2008). Gençler ve Sigara. Ankara: Klasmat Matbaacılık

Özdamar, K. (2002). Paket Programları İle İstatistiksel Veri Analizi (Çok Değişkenli Analizler) 2 (4. Bask1). Eskişehir: Kaan Kitapevi

Peker, M. ve Mirasyedioğlu, Ş. (2003). Lise 2. Sınıf Öğrencilerinin Matematik Dersine Yönelik Tutumları ve Başarıları Arasındaki İlişki. Pamukkale Üniversitesi Eğitim Fakültesi Dergisi, 2(14), 157-166

Ritchey, P.N., Reid, G.S. ve Hasse, L.A. (2001). The Relative Influence of Smoking on Drinking and Drinking on Smoking among High School Students in a Rural TobaccoGrowing Country. Journal of Adolescent Health, 29, 386-394

Shaw, M., Mitchell, R. ve Darling, D. (2000). Time for a Smoke? One Cigarette Reduces Your Life by 11 Minutes. BMJ, 320, 53-59

Soydal, T. ve Ergüder, T. (2002). Türkiye’de Sigara Sorunu ve Mücadelesi. Ankara: T.C. Sağlık Bakanlığı Temel Sağlık Hizmetleri Genel Müdürlüğü Yayınları.

Şahin, E. M. ve Tunç, Z. (2008). Öğretmenlerin Sigara Bırakma Davranışlarının Transteorik Modele Göre İncelenmesi. Türkiye Aile Hekimliği Dergisi, 12(3), 142-148

Talay, F., Kurt, B. ve Tuğ, T. (2008). Eğitim Fakültesi Sınıf Öğretmenliği Öğrencilerinde Sigara İçme Alışkanlıkları ve İlişkili Faktörler. Tuberk Toraks, 56(2), 171-178 
Tatlıdil, H. (1996). Uygulamalı Çok Değişkenli İstatistiksel Analiz. Ankara, Cem Web Ofset Ltd. Şti

T.C. Sağlık Bakanlığı (2014). Türkiye Halk Să̆lı̆̆ı Kurumu Küresel Yetişkin Tütün Araştırması Türkiye 2012. Ankara: Anıl Matbaa Ltd. Şti. http://www.halksagligiens.hacettepe.edu.tr/KYTA_TR.pdf adresinden alınmıştır.

Turhan, E., İnandı, T., Özer, C. ve Akoğlu, S. (2011). Üniversite Öğrencilerinde Madde Kullanımı, Şiddet ve Bazı Psikolojik Özellikler. Türkiye Halk Sağlı̆̆ Dergisi, 9(1), 33 44

Yazıcı, H. (2007). Sigara İçen ve İçmeyen Üniversite Öğrencilerinin Sigara İçmeye İlişkin Tutumlar1. Aile ve Toplum, 3(12), 83-90

Yazıcı, H. ve Şahin, M. (2005). Üniversite Öğrencilerinin Sigara İçme Tutumları ile Sigara İçme Statüleri Arasındaki İlişki. Kastamonu Eğitim Dergisi, 13(2), 455-466

World Health Organization WHO. (2015). Global Report on Trends in Tobacco Smoking 2015. http://apps.who.int/iris/bitstream/handle/10665/156262/9789241564922_eng.pdf?sequ $\underline{\text { ence }=1}$ adresinden alınmıştır.

Wu, J.D., Milton, D.K., Hammond, S.K. ve Spear, R.C. (1999). Hierarchical Cluster Analysis Applied to Workers' Exposures in Fiberglas Insolution Manufacturing. The Annals of Occupational Hygiene, 43(1), 43-55. 


\section{Summary}

\section{Problem Statement}

To determine which variables influence mathematical success, the relationships between the variables involved, and how much of the mathematical success can be explained by these variables, studies are needed that examine the effects of mathematical success on the variables involved. At this point, the relationship between prospective mathematics teachers' knowledge, attitudes and behaviors related to smoking with mathematics achievement was examined, and mathematics success was tried to determine the predictor's power. However, studies on smoking in Turkey are set forth in the prevalence of smoking habits, but the relationship of people with mathematics achievement and attitude in which they smoke for reasons related issues and behavior have not been studied enough.

Purpose of the Study: The aim of this study is to determine the clustering tendency of mathematics teacher candidates their knowledge, attitudes and behaviors related to smoking. In addition, the power of predicting the mathematical success of prospective mathematics teachers in this study was searched

\section{Method}

In the study, prospective mathematics teachers who are one of the sample groups in Çelik 's (2004) doctoral dissertation study are selected and data about smoking is analyzed. The research is in the relational screening model. In this present study, a relational screening model was chosen at the point where data indicating the relationship between knowledge, attitudes and behaviors related to smoking and math success were obtained.

The research group formed 148 smoking prospective mathematics teachers, studying at the faculty of education, mathematics education program. The research data were collected through personal information form, smoking questionnaire and math achievement means. 


\section{Findings}

In this study, $27.7 \%$ of the prospective mathematics teachers who smoked and $72.3 \%$ of the women were male. The mean age at the start of cigarette smoking was $15.89 \pm 2.71$ years. The mean number of cigarettes smoking per day is $19.22 \pm 8.43,48.6 \%$ of them smokes between 19-27. However, the mean smoking duration is $6.56 \pm 4.16$ years. The first factor affecting prospective mathematics teachers smoking was "friends" with $75.7 \%$. The dendogram obtained as a result of the applied Ward's connection technique, the smokingrelated variables of the prospective mathematics teachers were collected in three clusters as $\mathrm{C} 1, \mathrm{C} 2$ and $\mathrm{C} 3$. Four variables $(\mathrm{X} 12, \mathrm{X} 13, \mathrm{X} 22, \mathrm{X} 23)$ in the cluster $\mathrm{C} 1$ and Fourteen variables (X12, X13, X22, X23) The C3 cluster contains six variables (X7, X8, X9, X11, X16, X17). Multiple regression analysis was performed to calculate the math power of the related clusters in relation to the clustering tendencies of the smoking variables of the prospective mathematics teacher. According to this, $\mathrm{C} 1, \mathrm{C} 2$ and $\mathrm{C} 3$ together showed a moderate and significant relationship between mathematics achievement scores of the prospective mathematics teachers. Together, the relevant clusters together account for about $55 \%$ of the total variance in mathematical success.

\section{Discussion and Conclusion}

In this study, prospective mathematics teacher started to cigarette smoking as early adolescence, had continuous smoking for six years, and smoked a pack of cigarettes a day. Another finding is the fact that the first factor in the smoking of prospective mathematics teacher is the nearby environment.

Three clusters were formed as a result of the clustering analysis applied to the smokingrelated variables of the prospective mathematics teachers. The $\mathrm{C} 1$ cluster is called "Cognitive awareness of smoking" because it involves variables that reflect the perceived health risks of 
individuals who are informed of non-smoking, the non-smoking satisfaction and the health risks. In addition to the belief that the $\mathrm{C} 2$ cluster may be vulnerable to weight gain, inability to do business and to the transit in the case of cigarette abandonment, it has been named the "Cigarette addiction and effects" cluster because it reflects the dependency situations that it unintentionally burns because the cigarette is now a habit. Finally, C3 cigarettes are referred to as "perceptual stimuli and environment for cigarettes", because the stimuli on cigarette packs have positive effects on cigarette smoking cessation, passive smokers 'feelings about cigarette smoke, the environment, and especially the doctors' variables related to cigarette smoking cessation warnings. Investigations to assess attitudes and behaviors related to cigarette smoking or to investigate the cluster tendencies of smoking patterns have shown that clustering methods have been successful / meaningful for such structures.

As a result of the multiple regression analysis, the mathematics success of the prospective mathematics teacher was taken as a dependent variable and the level of the three clusters obtained from the clustering analysis was calculated. The three relevant clusters together account for about $55 \%$ of the total variance in mathematical success. Moreover, the relative importance order of the predicted clusters on mathematical success; "Cigarette addiction and effects", "Perceptual stimuli and environment for cigarettes" and "Cognitive awareness about smoking". From this it can be said that the tendency of the prospective mathematics teacher to climb on the knowledge attitudes and behaviors related to smoking is effective on the mathematical success.

\section{Suggestions}

Clustering analysis, which is one of the multivariate statistical methods in this study, provided similar, interesting and successful clusters in the analysis of prospective mathematics teachers' variables related to smoking, making it easier to evaluate. Conclusions about the 
degree of success of prospective mathematics teacher in predicting mathematical success can contribute to anticipating attitudes and behaviors in achieving more effective learning and success in teaching activities. Although this study focuses on prospective mathematics teachers' attitudes and behaviors towards smoking, each of the features found can be considered as factors that can be evaluated for mathematical success. In this context, it is suggested that researchers who will be studying should consider these characteristics. 